\title{
Public Services Advertising Community Movement Program "GERMAS" Public Health, Batu Bara District through Radio Odan FM
}

\author{
Sahdin Hasibuan ${ }^{1}$, Erwan Efendi ${ }^{2}$, Arief Rahman ${ }^{3}$ \\ 1,2,3 Universitas Islam Negeri Sumatera Utara, Medan, Indonesia \\ rarief112@gmail.com
}

\begin{abstract}
The purpose of this study was to find and study about public services advertising community movement program "GERMAS" public health. This research is in the form of field research. Field research is research that is aimed directly at the location of the research to be studied, namely in a community, agency or company to search for data and then observe and conclude. Based on the results of the discussion in the previous chapter, it can be concluded that the public service advertisement broadcast of the GERMAS program broadcast by Odan FM Radio is effective, because listeners find it helpful to have information in the form of advertisements delivered through Odan Radio broadcasts, where many people follow several the points in the GERMAS program, although there are still people who do not know about and participate in this GERMAS program, where there are deficiencies felt by the Health Office in delivering the GERMAS program in the community.
\end{abstract}

Keywords

public services, advertising

community, public health

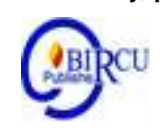

\section{Introduction}

Mass communication according to Onong Uchjana Effendy is communication through modern mass media which includes newspapers that have a wide circulation, radio and television broadcasts aimed at the public, and films shown in cinemas.

Mass communication can also be defined as the process of communication carried out through the mass media with various communication purposes and to convey information to a wide audience. Thus, the important elements in mass communication are communicators, media, mass, information, gatekeeper, audience feedback. It is common for modern mass media to represent a whole system in which messages are produced, selected, broadcast, received and responded to. Mass communication broadcasts large amounts of information, ideas and attitudes to various communicants using the media.

Advertising is not only commercial in nature, advertising is also social. Also known as

the Public Service Announcement or Public Service Announcement, Public Service Announcements place more emphasis on the public interest which seeks to instill awareness in the wider community that is considered important. Advertisements are designed to give advice to people so that they use a certain product or service, forming a desire to have and consume it regularly. Advertising design starts with paying attention to actuality, message appeal, selection of appropriate media, the intended target audience, truly effective effects, low cost and affordable to all consumers. (Bara et al, 2021)

Advertising offers a value system in social life, in terms of psychology, advertising affects a person's motivation in making decisions and acting. Whereas, in terms of advertising 
communication concerning the effectiveness of advertising media as an advertising communication tool concerning the effectiveness of advertising media as a communication tool. Advertising is one form of communication consisting of information and ideas about a product that is aimed at the audience simultaneously in order to get a good reception. Advertising tries to provide information, persuade and convince. (Suharyanto and Hidayat, 2018)

Mass media, especially radio, is designed to create an image and imagination for listeners by using the power of words and sounds. Radio as a mass communication medium that is widely used by the public has now turned into a popular business organization.

The rapid development of radio is marked by the full frequency and advertisers placing advertisements on radio stations. Radio is capable of reaching a certain number and group of listeners because of the advantages that radio has as an electronic media compared to other media. The advantages of radio are that it is flexible, inexpensive and more personal, therefore many people use radio from the lower classes to the upper classes. Another advantage of radio is its wide broadcast coverage so that it can be enjoyed even in regions. Radio is an auditive mass media used by listeners and its broadcast content is cursory and cannot be repeated.

In line with the need for radio by the wider community, of course it is the responsibility of radio managers in carrying out radio functions that are truly beneficial to the interests of the public and not concerned with their own interests. Radio stations are becoming an industry that places itself in competition for business for commercial gain in its survival.

\section{Review of Literatures}

\subsection{Definition of Advertising}

Advertising is used to inform a product in the form of goods, services or ideas. In its development, advertising no longer functions as a tool to introduce products for sale, but is also used as a tool to create a positive image for companies or institutions in the eyes of the public, advertisements are also made by non-governmental organizations (non-profit) in conveying messages that have a purpose different in other formal institutions.

Advertising is commercial communication about an organization and its products which are transmitted to a target audience through mass media in printed media, direct mail (direct posting). Shaped like outdoor billboards, or public transportation. In Mandailing Natal, the community defines advertising as any form of message about a product or service that is conveyed through a media and addressed to part or all of the community. Meanwhile, the term advertising is defined as the whole process which includes the preparation, planning, implementation and monitoring of advertisement delivery. (Jefkins in Bara, 2021)

Basically, advertising is always related to the rental of space in the mass media, which is certainly quite a burden. Griffin and Ronald J. Ebert define: "Advertising is an activity that costs money, non-personal communication is used by certain sponsors to convey to the audience about a product"

Advertising is a means used to convey information, especially with regard to products or other information that requires public attention. Advertising is commercial and nonpersonal communication about an organization and its products that are transmitted to a target audience through mass media such as television, radio, newspapers, magazines, direct mail, billboards, outdoor, public transportation.

Other definitions of advertising are as follows: According to Kenedy and Soemanagara, the purpose of advertising is ultimately to increase changes in consumer attitudes and 
behavior. Communication strategy properly designed will produce the desired action. Following are the main objectives of advertising activities.

1. Make the audience aware and provide information about a product, service or idea.

2. Cultivate in the audience a feeling of liking the goods, services or ideas presented by giving them a perception.

3. Convince the audience of the truth about what is recommended in the advertisement and therefore mobilize it to try to own or use the recommended goods or services.

In essence, advertising is to introduce a product to potential buyers (consumers). "The ultimate goal of advertising is to influence someone to behave in accordance with what the advertiser wants.

Thus that the purpose of advertising is ultimately a change in attitudes and behavior of the audience or individuals who are the target of the advertisement, changes in attitudes and behavior desired by advertisers. The result of advertising is determined by the action, this action is indicated by a change after the advertisement informs the ad in the mass media. Action depends on the message conveyed, whether it is in accordance with the expected goals or not.

\subsection{Definition of Healthy Community Movement (GERMAS)}

The Healthy Society Movement (GERMAS) is a systematic and planned action carried out jointly by all components of the nation with awareness, willingness and ability to behave healthy to improve the quality of life. The implementation of GERMAS starts from the family, because the family is the smallest part of society that shapes personality.

GERMAS is a movement that aims to promote a culture of healthy living and increase the habits and behavior of people who are less healthy. The GERMAS action was also followed by promoting hygiene and healthy living habits and support for community-based infrastructure programs.

GERMAS is a national movement initiated by the President of the Republic of Indonesia that puts forward promotional and preventive efforts, without neglecting curativerehabilitative efforts by involving all components of the nation in promoting a healthy paradigm. To succeed GERMAS, we cannot rely solely on the role of the health sector. The role of Ministries and institutions in other sectors also determines, and is supported by the participation of all levels of society. Starting from individuals, families, communities in practicing a healthy lifestyle, academics, the business world, community organizations, and professional organizations in mobilizing their members to have a healthy behavior; as well as the Government, both at the central and regional levels, in preparing supporting facilities and infrastructure, monitoring and evaluating their implementation.

This program has several focuses, such as building access to meet drinking water needs, community health installations and building habitable settlements. The three of them are the basic infrastructure that is the foundation of the healthy living community movement. This program has several focuses on building access to meet the needs of drinking water, public health installations and the development of habitable settlements, the three of which are basic infrastructure that serves as the foundation and movement of healthy living communities.

The GERMAS logo, which seems simple, has deep food; knowing the meaning behind the logo can be the beginning to better understand and appreciate the Healthy Society Movement which has been designed since 2015. In the logo there are three fields in turquoise blue which are the symbols of the 3 Pillars of the Healthy Indonesia Program. The three pillars are the application of a healthy paradigm, strengthening health services and national health insurance. 


\subsection{Radio Definition}

Radio is a communication technology by sending signals via electromagnetic waves, radio is a very sophisticated communication technology at its time. Where Pete Schullerg mentions radio media as "the arena of fantsy, the theater of mid", this defines radio as a medium that is personal, the ultimate personal medium. Radio is a medium that can be heard anywhere, anytime and while you are: at home while relaxing, in the car while driving, in the fields while plowing, and in the office while typing. Radio can greet its listeners with very personal idioms. Another character of radio is local.

Radio is one part of the mass media which is classified as electronic media. Radio has its own characteristics and advantages compared to other mass media. Radio characters, namely: fast delivery of messages, wide reach unobstructed by place, position, time and can be brought and heard anywhere and anytime. Radio positions itself as a medium for broadcasting news setra with other strategic media such as print media and television. As part of mass communication

Radio can be interpreted in three definitions, namely: mass communication directed to a relatively large, heterogeneous, and anonymous audience; messages that are disseminated in general, are often scheduled to reach as many audience members as possible simultaneously and are temporary: their equivalent communicators tend to be in or operate in a complex organization that may be costly.

\subsection{History of the establishment of Radio Odan FM}

Radio Odan FM was established in 2016 and officially launched in early March 2017, with the aim of being a communication medium for an educational source of information, entertaining the listening community, especially the people of Batu Bara Regency and surrounding areas that get a series of broadcasts. Radio Odan FM was founded by the Batu Bara Regency government which is regulated in Perda Number 8 of 2016 concerning the Establishment of Local Public Broadcasting Institutions FM Odan Radio and Odan Television in Batu Bara Regency

Radio Odan FM is the government-owned media of Batu Bara Regency which can be used as a unifying media for the community through the delivery of information on government policies as well as a means of promotion and entertainment that is attractive to the community.

A radio achieves its success when viewed from 2 aspects, namely the number of advertisements and the number of listeners. As well as succeeding in making employees prosperous, the radio will produce a good program. Radio Odan FM is the only radio located in Batu Bara Regency and is directly monitored by the Kominfo office of Batu Bara Regency, which has an address at Jln. Lintas Gambus Laut, Lima Puluh Pesisir District, Batu Bara Regency. Radio Odan FM is on the 89.3 FM frequency and has been broadcasting since 2017. Early on air or broadcast hours starting at 06.00-20.00 WIB with various kinds of program programs according to the segmentation.

Radio Odan FM as the only local radio certainly wants to be accepted by all levels of society and wants to be part of the community itself. Because of that, Radio Odan also positions itself as a family radio by entering a typical native Malay word, namely Odan which means "me or me" and make a tagline like radio in general. The tagline is the identity of Radio Odan which always explores and prioritizes the works of the nation's children. 


\subsection{Characteristics of Mass Communication}

According to Michael W. Gamble and Teri Kwal Gamble in their book Introducing Mass Communication. Something that can be said of mass communication includes: Communicators in mass communication rely on modern equipment to disseminate or transmit messages quickly to a wide and dispersed audience. Communicators in mass communication disseminate messages intending to try to share understanding with millions of people who do not know each other or know each other. Between the sender and recipient of the message do not know each other. Then, Message is public. This means that this message can be obtained and received by many people and not for a specific group of people. Then the message can be interpreted as belonging to the public. Another characteristic according to Michael is that as a source of mass communicators, it is usually formal organizations such as networks, ties or associations. In other words, the communicator did not come from someone,but institutionalized. These institutions are usually oriented towards economic gain and are not voluntary or non-profit organizations. Mass communication is controlled by the gatekeeper (information pentapis). This means that messages that are spread or transmitted are controlled by a number of individuals in the institution before being broadcast through the mass media. Feedback in mass communication is delayed in nature.

\section{Research Methods}

This research is in the form of field research. Field research is research that is aimed directly at the location of the research to be studied, namely in a community, agency or company to search for data and then observe and conclude. Field research is carried out in real life. Basically, this field research is a method for finding specific and realistically about what is happening at some point in the midst of people's lives. In principle, this field research aims to solve practical problems in society

The purpose of this method is a broad and deep understanding of a problem that is being studied. The data collected is more letters, words and facts than numbers. According to Moleong, citing Bodgan and Taylor's opinion, suggesting that qualitative research produces descriptive / descriptive words in the form of written or spoken words of the behavior of actors that can be observed in social situations.

Krik and Miller quoted by Syukur Kholil in the book Communication Research Methodology explained that qualitative research is a particular tradition in social science which fundamentally depends on human observation and its own area and relates to these people in their language and terminology. Each event is an essential concern in qualitative research, it cannot be explained in numbers. The results of the research are described in accordance with what is in the field even if you can use hidden values, you are more sensitive to descriptive information and try to maintain the integrity of the object that is careful.

The approach used is a phenomenological approach. The phenomenological approach is an approach used to understand, explore, and interpret the meaning of events, phenomena and relationships with people in certain situations. This type of descriptive qualitative research is used to describe the results of the research in the form of a description of facts and words. Syukur Kholil in his book Communication Research Methodology said that research research that is descriptive tends to use analysis and emphasizes the process of meaning.

The problem raised in this study is the Effectiveness of Public Service Advertisements for the Healthy Community Movement Program "GERMAS" Batu Bara District Health Office Through Odan Radio, researchers collected data obtained by conducting a pre-survey on Radio Odan. 
Qualitative methods can also be used to uncover and understand something behind a phenomenon that is not even at all known and can be used to gain insight into something that is little known and provide complex details about phenomena that are difficult to reveal by other methods. The research subject is the source where we get research information or someone or something about which we want to get information. Those who become research subjects are people who have the ability and willingness to answer questions from researchers so that information related to research is obtained.

As for the subjects of this research are the management staff of Odan FM Radio who are involved in the broadcast program, consisting of the head of the Odan FM Radio studio, the Head of the Broadcast Executing Division (Program Director), Broadcasters (Moderators) and other parties who are considered to have an important role in broadcast programs. Public Service Advertisement for Healthy Community Movement Program.

\section{Result and Discussion}

Radio Odan is a government radio in Batu Bara Regency. As it should be, Radio Odan has carried out its function and role as mass media, namely as a medium for providing information, entertainment media, social control media and this is in accordance with Broadcasting Law No. 32 of 2002 paragraph 1 states that every broadcast content in the mass media must contain information, education and entertainment. In addition, it is also stated that broadcast content must be useful for intellectuality formation and practice religious and cultural values.

The GERMAS program which is broadcast through Radio Broadcasts which is conveyed in the form of advertisements is more conveyed to the public, of the six points contained in the GERMAS program there are several points that become benchmarks for the success of this GERMAS program which is broadcast on Odan FM Radio such as:

1. Doing physical activity in a day

2. Protect the environment and

3. Not Consuming Alcoholic Drinks

According to Akhsanul Rizqy Harahap Sekalu Director at Radio Odan that there are several forms of broadcasts in the form of Public Service Ads in addition to public service advertisements for the GERMAS program from the Coal Health Service which are broadcast on Odan Radio, there are also advertisements from several other agencies, namely, Licensing Service advertisements, advertisements The Koprasi Office, the Public Prosecutor's Office advertisement, and the BNN advertisement and these advertisements are often broadcast on Tuesday during the broadcast. According to him, this advertising program is like the public service advertisement of the GERMAS program beneficial to listeners. Can increase public awareness to follow a healthy lifestyle according to recommendations from the government. In connection with this thesis research, the researcher conducted interviews with 7 respondents in three sub-districts of Batu Bara Regency, namely interviews with Marubiah and Sayani who are located in Lima Puluh District, Fery Putra and Khamaruddin, respondents from Lima Puluh Pesisir District, Ainun respondents from Tanjung Tiram , Bariah and Irma having their address at Sei Balai Village.

Researchers also interviewed 2 radio announcers Odan named Mr. Samsul, S.pd and Mr. Zulfan, S.pd in broadcasting public service announcements to listeners. The effectiveness of public service advertisement broadcasts carried out on Odan Radio can be said to be effective if many radio broadcast listeners listen to broadcast programs through Odan Radio, it is known from the results of interviews. 


\subsection{Mrs. Marubiah}

Mrs. Marubiah, 45 years old, address Simpang Dolok Kec.Lima Puluh "Yes, I hear Odan Radio broadcasts and sometimes I also hear about GERMAS Ads through Odan Radio broadcasts, yes, not always at first, but sometimes I take the time to follow his advice, although not all I follow, at least I am active in physical activity. Such as following a healthy afternoon exercise program which is carried out by the Coal Health Office in collaboration with Radio Odan and I also maintain an appropriate diet ".

\subsection{Mrs. Sayani}

Mrs. Sayani, 30 years old, address Simpang Dolok Kec. Lima Puluh Dusun II. Saying that "I don't really understand GERMAS, but in 4 weeks I often hear it on the radio there I hear that I eat vegetables and fruit, I don't smoke, if I eat it, of course I don't eat fruit too often, sir, my name is also the pengahassilan normal, but thank God, every day, thank God, my child and my husband don't smoke

The statement stated that listeners did not really know about the GERMAS Program, and listeners knew it when this program was broadcast via radio broadcasts.

\subsection{Mr. Fery Putra}

Fery Putra, 25 years old, address of Perupuk Dusun V Kec. Lima Puluh Pesisir who admit that he is an active listener in listening to Radio Odan "yes sir, I know the GERMAS program and I also listen to it through the Every Must Know program and I follow the program every morning around 10.00 WIB" In the follow-up interview, the respondent said that "from several points in the GERMAS Program, there are several points that I follow, such as not smoking, not drinking alcoholic drinks, maintaining the environment and doing physical activities76. Some of the explanations above can be understood that there are people in Batu Bara Regency. Who listen actively to the Community Service Announcement of the GERMAS program through Odan Radio and feel the positive impact in their daily life. Even in 2020

Public Service Announcements for the GERMAS Program broadcast on Odan Radio are also said to be effective if they deliver the listener's understanding in achieving the goal of understanding GERMAS and carry out the recommendations contained in the broadcast program. Conversely, it is said to be ineffective if it does not trigger the development of the understanding ability of GERMAS to the listener, as expressed by:

\subsection{Mr. Ainum}

Sister Ainun, a midwife in Batu Bara, having her address at Jln. Rahmadsyah Dusun II Kec. Tanjung Tiram and 35 years old. "Yes, I like the GERMAS Ad broadcast broadcast by Radio Odan, because the advertising material is clear from all the points conveyed with elements of society and cultural elements at the end of the advertisement what's more this ad helps me by inviting the public to run the points in this GERMAS where every activity at the posyandu we always do clean and clean the environment and this broadcast also helps me in advising the community the importance of maintaining health to the surrounding community

\subsection{Mrs. Bariah}

Bariah is 45 years old, her address is Jalan Lintas Sei Balai, giving her opinion about social media-based radio as a medium for delivering messages.

"Yes, I listen to live radio broadcasts using Facebook. In my opinion, if we listen to the live media on Facebook, we as listeners feel close to the poet, the lines we don't know who is speaking, so now we know the appearance of the person presenting the broadcast, then we 
become more familiar with broadcasters and we can send messages or ask questions. right away, so in my opinion, just right, it is very suitable for this GERMAS Ad program to be broadcast because the form of information is indeed important to do at times like this, where I now focus more on following routine exercise and sports programs "

This statement states that listeners prefer to listen to radio broadcast programs through social networking media, namely Facebook compared to conventional radio, but in broadcasting that requires an internet network to access, the problem is that when the internet network experiences interference, access to listen to broadcast programs is cut off. The results of the interview with one of the other respondents also revealed

Effectiveness can be interpreted as the result of something. In this case it can be understood as changes that have occurred in the community, especially listeners of Odan FM Radio after hearing the Public Service Announcement broadcast of the GERMAS Program. Radio as mass media also has a function as an educational medium, information media and social control for society. Radio media can invite the public persuasively. The changes that occur in society after listening to the radio include:

\section{a. Cognitive Change}

According to several sources that the researchers interviewed, that some of them listened to the GERMAS program Public Service Announcement broadcast not only in terms of listening, but also in the form of thoughts. This means increasing their knowledge about the GERMAS program which they already knew at first. And they do it even though it's not perfect. For example, check your health regularly. However, this recommendation has not been implemented.

\section{b. Affective Change}

These changes are changes that are higher in level than cognitive changes. In affective change, the listener not only adds knowledge or information but creates a sense of something in his heart. Radio Odan apart from being a medium of entertainment also provides educational programs, government and also social information. In the affective view, when people, especially listeners, about social information such as the GERMAS Program, there will be a sense of responsibility to carry out this activity in the family. In the affective realm, there will be a community emotional effect that arises from following the points in GERMAS such as not doing physical activities and protecting the environment.

\section{c. Behavior Change}

Behavior effects are effects that arise in the form of behavior that occurs in Radio Odan listeners. Behavior change is a change in behavior that occurs in listeners after listening to or getting new information. If the public, especially Odan Radio listeners, listen to the GERMAS Program Public Service Advertisements which contain health information starting from the family, in this situation the public, especially Odan FM Radio listeners, will follow the program at GERMAS.

Obstacles that are obtained based on the results of this study are those originating from the Health Office and Radio Stations. So far, information dissemination for the GERMAS program used to be only through Lifleat and brochures and banners. The lack of budgeting is due to a long process, plus the lack of human resources (HR) with a background in health promotion education, and communication, the lack of training for officers in the field and the lack of innovation in the use of media in disseminating information about the GERMAS program83, while the obstacles from radio are the lack of adequate equipment in broadcast broadcasting and the broadcast coverage is still not broad 


\section{Conclusion}

Based on the results of the discussion in the previous chapter, it can be concluded that the public service advertisement broadcast of the GERMAS program broadcast by Odan FM Radio is effective, because listeners find it helpful to have information in the form of advertisements delivered through Odan Radio broadcasts, where many people follow several the points in the GERMAS program, although there are still people who do not know about and participate in this GERMAS program, where there are deficiencies felt by the Health Office in delivering the GERMAS program in the community.

\section{References}

Agustrijanto. (2002) Copywriting; Seni Mengasah Kreativitas dan Memahami Bahasa Iklan, Bandung: Remaja Rosdakary.

Agus, Madjadikara. (2004). Bagaimana Biro Iklan Memproduksi Ikla. Jakarta : PT. Gramedia Pustaka.

Amir Mafri, Etika. (1999). komunikasi Massa dalam Pandangan Islam, Ciputat: PT. Logos Wacana Ilmu.

Astrid Susanto. (1982). Komunikasi Massa, Bandung: Bina Cipta.

Antoni, Riuhnya. (2004). Persimpangan Itu: Profil dan Pemikiran Para Penggagas Kajian Ilmu, Solo: Tiga Serangkai.

Bara, A. et al. (2021). The Effectiveness of Advertising Marketing in Print Media during the Covid 19 Pandemic in the Mandailing Natal Region. Budapest International Research and Critics Institute-Journal (BIRCI-Journal). P. 879-886.

Bugin Burhan. (2006). Sosiologi Komunikasi: Teori, Paradigma, dan Diskursus Teknologi Komunikasi di Masyarakat, (Jakarta: Kencana Media group.

Ebert Ronald J. dan Griffin. (1996). "Bisnis, Buku Satu, Edisi ke-4, Jakarta. Furchan Arief, 1992 Pengantar Metode Penelitian Kuantitatif, Surabaya: Usaha Nasional.

Hardiman, Ima. (2006). Gagas Ulung Internasional Jakarta; Media dan Periklanan.

Kenndy, Jhon, E, R Dermawan Soemanagara, Marketing Comunication-Taktik dan Strategi, Jakarta, PT Buana Ilmu Popular.

Kholil Syukur. (2007). Komunikasi Islam, Bandung: Citapustaka Media.

Lexy J. Moleong. (1993). Metodologi Penelitian Kualitatif, Bandung: Remaja Rosdakarya.

Lee, Monle dan Jhonson. (2007). Prinsip-Prinsip Priklanan Dalam Perspektif Global, Terjemahan Haris dan budi Priatna.

Liliweri Alo, Dasar-dasar Komunikasi Periklanan, Bandung: PT Cintra Aditya Bakti.

Masduki, et.al. (2007). Jurnalistik Radio Menata Pofesional Reprter dan Penyiar, Yogyakarta: Lkis.

Mufid Muhammad. (2005). Komunikasi \& RegulasiPenyiaran, Jakarta: Kencana prenada Media Group.

Nurdin. (2007). Pengantar Komunikasi Massa, Jakarta PT Raja Grafindo Persada.

Pujiyanto. (2013). Iklan Layanan Masyarakat, Yogyakarta: CV Andi Offset. Sohoturon Yussi 2009, "Efektifitas Radio Sebagai Media Penyiaran Islam pada

Bulan Ramadhan bagi Masyarakat Islam di Kota Medan",Tesis, Program Pasca Sarjana IAIN Sumatra Utara.

S. Sari Endang, Audience Research (1993) Pengantar Studi Penelitian Terhadap Pembaca, Pendengar dan Pemirsa, Yogyakarta: Andi Offset.

Sugiyono. (2011). Metode Penelitian Pendidikan Pendekatan kualitatif, kualitatif, dan R\&D, Bandung: Afabeta. 
Suharyanto, A and Hidayat, T. (2018). Revealing Medan's Chinese Ethnic Identity in Advertising Grief at Harian Analisa Newspaper. Budapest International Research and Critics Institute-Journal (BIRCI-Journal). P. 83-92.

Uchjana Effendy Onong. (2005). Ilmu Komunikasi Teori dan Praktek, Bandung: PT Remaja Rosdakarya.

Undang-Undang Republi Indonesia No, 322002.

Wener J. Severin-james W. Tankard, JR. (2001). Teori Komunikasi Massa, Sejarah, Metode, dan Terapan di Dalam Media Massa, Jakarta: Kencana Prenada Media Group.

Widyatama Rendra. (2009) Pengantar Priklanan, Jakarta: Pustaka Book Wiryanto, 2008 Teori Komunikasi Massa, Jakarta: Grasindo.

\section{Internet}

https://dinkes.gorontaloprov.go.id/apa-itu-germas/ di akses pada tanggal 19 juni 2020

https://promkes.kemkes.go.id/germas diakses pada tanggal 19 Juni 2020 https://solusiprinting.com/iklan-layanan-masyarakat-pengertian-sejarah-dan

$\begin{array}{llllll}\text { fungsinya/ di akses } & \text { pada } & \text { tanggal } & 19 & \text { Juni } & 2020\end{array}$ https://www.seputarpengetahuan.co.id/2015/12/12-pengertian-iklan-menurut-

para-ahli-terlengkap.html di akses pada tanggal 19 Juni 2020 https://kbbi.kemdikbud.go.id/entri/iklan diakses pada tangga 19Junil 2020 https://www.kemkes.go.id/resources/download/profil/PROFIL_KAB_KOTA_201

5/1219_Sumut_Kab_Batubara_2015

https://batubarakab.bps.go.id/statictable/2015/04/01/5/letak-dan-geografi

kabupaten-batu-bara.html https://www.batubarakab.go.id/pages/selayang-pandang 